\title{
Assessing macroinvertebrate communities in relation to environmental variables: the case of Sambandou wetlands, Vhembe Biosphere Reserve
}

\author{
Tatenda Dalu $^{1}$ (D) $\cdot$ Rivoningo Chauke ${ }^{1}$
}

Received: 24 July 2019 / Accepted: 18 November 2019 / Published online: 29 November 2019

(c) The Author(s) 2019

\begin{abstract}
The Vhembe Biosphere Reserve, South Africa, contains many wetlands that serve as wildlife habitats and provide vital ecosystem services. Some of the wetlands are continuously being degraded or destroyed by anthropogenic activities causing them to disappear at an alarming rate. Benthic macroinvertebrates are known as good water quality bioindicators and are used to assess aquatic ecosystem health. The current study investigated habitat quality using macroinvertebrate community structure and other biotic variables (i.e. phytoplankton, macrophytes) in relation to environmental variables in the Sambandou wetlands using canonical correspondence analysis (CCA). A total of fifteen macroinvertebrate families were identified over two seasons. The CCA highlighted seven variables, i.e. $\mathrm{pH}$, phosphate concentration, temperature, ammonium, macrophyte cover, conductivity and water depth, which were significant in structuring macroinvertebrate community. Picophytoplankton and microphytoplankton concentrations decreased from winter to summer, whereas nanophytoplankton concentration increased from winter to summer. Thus, the dominance of small-sized phytoplankton indicated nutrient limitation and decreased productivity, whereas winter sites 2 and 3 were dominated by large-celled phytoplankton, highlighting increased productivity. Winter sites were mostly negatively associated with CCA axis 1 and were characterised by high temperature, phosphate and ammonium concentrations, macrophyte cover, $\mathrm{pH}$ and conductivity. Summer sites were positively associated with axis 1 , being characterised by high water depth and $\mathrm{pH}$ levels. The results obtained highlighted that agricultural activities such as cattle grazing and crop farming and sand mining/poaching had a negative effect on macroinvertebrate community structure.
\end{abstract}

Keywords Macroinvertebrates $\cdot$ Sambandou $\cdot$ Nutrients $\cdot$ Wetlands $\cdot$ Water quality $\cdot$ Phytoplankton $\cdot$ Macrophytes

\section{Introduction}

A wetland is an area that is permanently and/or temporally saturated with water (Alkorta and Garbisu 2001). Wetlands serve as natural purifiers of water, filtering and absorbing many pollutants in surface water, e.g. phytoremediation (i.e. removal of contaminants using plants) and bioremediation (i.e. degrade contaminants to less toxic using organisms), habitat for flora and fauna, grazing areas for animals, and tourism (Alkorta and Garbisu 2001; Malinga et al. 2015). These unique habitats support aquatic biodiversity, with a

Tatenda Dalu

dalutatenda@yahoo.co.uk

1 Department of Ecology and Resource Management, University of Venda, Thohoyandou 0950, South Africa high number of unique plant and animal species only found within these systems.

Wetlands are disappearing worldwide due to human activities such as agriculture, mining and urban development (Arheimer et al. 2005; Millennium Ecosystem Assessment 2005; Dalu et al. 2017a). Pollution within wetlands is a growing concern, since it has detrimental effects on human and aquatic species, and this is affecting the wetland biodiversity (Sayadi et al. 2010). Hence, a high number of aquatic species are at greater risk of extinction due to pollution caused by agriculture and other human-induced activities on wetlands (Dalu et al. 2017b; Nhiwatiwa et al. 2017a). Thus, there is a growing concern as very little has been done to address this issue.

According to Ollis et al. (2006), a bioindicator is an organism or a community of organisms that contains information on the environmental quality. Macroinvertebrates are the most frequently used and are known as potential 
bioindicators of water quality and hence are used to assess the health of an ecosystem (Bonada et al. 2006; Dalu et al. 2017c). Various studies (e.g. Allan 2004; Macedo et al. 2016; Mangadze et al. 2019) show that macroinvertebrates are the mostly frequently used organisms to assess wetland ecosystem health. Macroinvertebrates are reliable indicators because their life cycles are long enough to detect changes caused by any disturbances (Ollis et al. 2006). The sensitivity of macroinvertebrates to pollution vary (Rosenberg and Resh 1993), some macroinvertebrates are tolerant to water pollution, while others are sensitive. For example, Caenidae (mayflies) are sensitive to water pollution, whereas Culicidae (mosquito's larvae), Diptera (true flies) and Oligochaeta (worms) are tolerant to pollution. High macroinvertebrate diversity exists within wetlands which are not disturbed by anthropogenic activities (Brand and Miserendino 2015).

The study aimed to investigate macroinvertebrate community structure in relation to environmental characteristics within the Sambandou wetland, Vhembe Biosphere Reserve, South Africa. Habitat assessment (physical and chemical) variables were used to assess the key drives of aquatic macroinvertebrate community structure and composition within the wetland. More specifically, this research aimed to: (1) determine the macroinvertebrate's community structure and composition across seasons within the wetland, (2) assess the impact of environmental characteristics on macroinvertebrate community structure and composition and (3) assess wetland integrity using macroinvertebrates, environmental variables and habitat variables in conjunction with community metrics. This study will assist in answering emerging question on agricultural activities in wetlands and how human activities affect wetland integrity. With water being a scarce resource in South Africa, a lot of people, especially in rural areas, depend on wetlands as their water source and a form of sustaining their livelihoods through ecosystem services the wetland provides.

\section{Materials and methods}

\section{Study area}

The Sambandou wetlands are located in quaternary A92B of the Luvuvhu catchment towards the north-east of Thohoyandou, Limpopo Province, South Africa. Sambandou wetlands are channelled valley-bottom wetlands and about 203 ha in size. The wetland system is associated with the Sambandou River, a tributary of the Mutale River. This wetland system is utilised for agricultural purposes, i.e. cultivation and livestock grazing, and as water source by the local communities, and it is thus important for maintaining the ecosystem integrity and ensure the sustainability of the services it provides. Furthermore, downstream users depend on the wetland for ecosystem services such as flood attenuation and water filtration. The wetland is undergoing significant channel incision and sediment deposition, which effectively is lowering the water table. The study was conducted in winter (June 2017) and summer (October 2017). Four sites were selected from the wetland: one site in the upper reach (located next to village households and also utilised as grazing field), one site in the lower reach (i.e. utilised as gardens, grazing and had high activities of illegal sand mining) and two sites in the middle reaches which were dominated mostly by village households next to the wetland, with a lot of gardens within the wetland (Fig. 1).
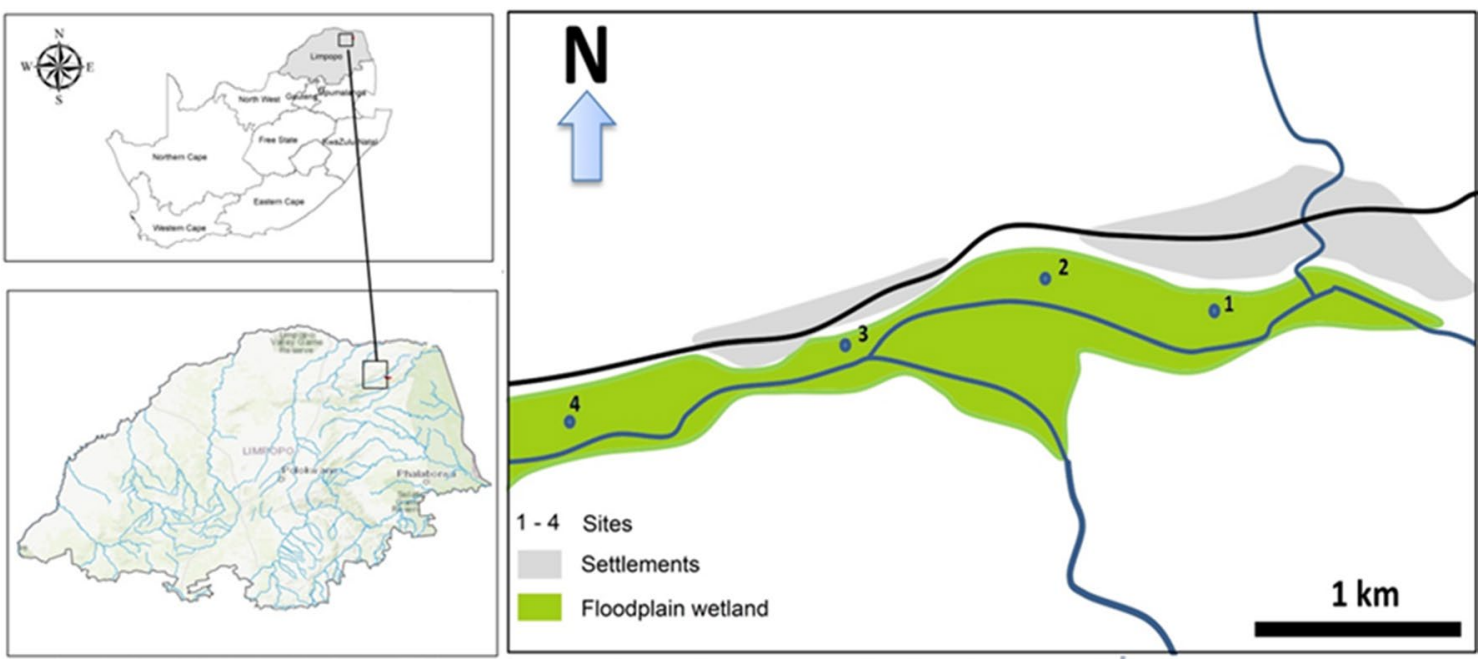

Fig. 1 Map highlighting the location Sambandou wetland and the selected study sites

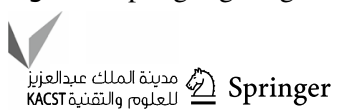




\section{Environmental variables and water sampling}

Environmental variables such as conductivity $\left(\mu \mathrm{S} \mathrm{cm}^{-1}\right)$, dissolved oxygen $\left(\mathrm{mg} \mathrm{L}^{-1}\right)$, total dissolved solids $\left(\mathrm{mg} \mathrm{L}^{-1}\right)$, $\mathrm{pH}$ and temperature $\left({ }^{\circ} \mathrm{C}\right)$ were measured using a portable hand-held multi-parameter probe PCTestr 35 (Eutech/Oakton Instruments) in situ from three different points per site. A tape measure was used to measure the water depth and channel width.

Two polyethylene bottles $(250 \mathrm{~mL})$ were filled with wetland water from each site for nutrients (i.e. phosphate, ammonium), turbidity and size-fractionated chlorophyll- $a$ (i.e. macro-, pico- and nanophytoplankton) analyses. In the laboratory after filtration of the water samples for chlorophyll- $a$ concentration determination, ammonium and phosphate concentrations were analysed using an ammonium test kit for freshwater (HI3824), with a range of $0-2.5 \mathrm{mg} \mathrm{L}^{-1}$ and a $0.5 \mathrm{mg} \mathrm{L}^{-1}$ resolution and Hanna phosphate high range checker (HI717) (Hanna Instruments, Romania, with a $0-30 \mathrm{mg} \mathrm{L}^{-1}$ range and $0.1 \mathrm{mg} \mathrm{L}^{-1}$ resolution.

\section{Size-fractionated chlorophyll-a concentration determination}

Size-fractionated pelagic phytoplankton biomass was determined by measuring chlorophyll- $a$ (chl- $a$ ) concentration from site ( $n=4 \times 2$ replicates) to tell us more about the state of the ecosystem in terms of primary productivity. Collected water samples $(250 \mathrm{~mL})$ were serially filtered (vacuum of $<5 \mathrm{~cm} \mathrm{Hg}$ ) through a 20- $\mu \mathrm{m}$ Nitex nylon mesh filter (microplankton, $>20 \mu \mathrm{m}$ ), a 2- $\mu \mathrm{m}$ Millipore isopore membrane filter (nanoplankton, 2-20 $\mu \mathrm{m}$ ) and a $0.7-\mu \mathrm{m}$ Whatman GF/F filter (picoplankton, 0.7-2 $\mu \mathrm{m}$ ) (Sieburth et al. 1978). After filtration, the filters inserted in separate labelled bottles containing $10 \mathrm{~mL}$ acetone and stored in the dark for $24 \mathrm{~h}$ to allow chl- $a$ extraction. After $24 \mathrm{~h}$, chl- $a$ concentration was determined using SPECTROstar NANO (BMG LabTech $\mathrm{GmbH}$, Ortenberg) according to Lorenzen (1967):

$$
\begin{aligned}
\mathrm{Chl}-\mathrm{a}\left(\mathrm{mg} \mathrm{m}^{-3}\right)= & 11.4 \times K \times\left(\left(665_{\mathrm{o}}-750_{\mathrm{o}}\right)\right. \\
& \left.-\left(665_{\mathrm{a}}-750_{\mathrm{a}}\right)\right) \times V_{\mathrm{e}} \div L \times V_{\mathrm{f}}
\end{aligned}
$$

where $L$-cuvette light-path $(\mathrm{cm}), V_{\mathrm{e}}$-extraction volume (mL), $V_{\mathrm{f}}$-filtered volume (L) and $K-2.43$.

\section{Macroinvertebrates sampling}

At each site and season, benthic macroinvertebrates were sampled using the kick sampling method according to Dickens and Graham (2002). In summary, a hand-held kick net (dimensions $30 \times 30 \mathrm{~cm}$, mesh size $500 \mu \mathrm{m}, 1.5 \mathrm{~m}$ handle) was used to sample all the available habitat types. The handheld kick net was submerged in the water, macroinvertebrates were collected by sweeping within a certain area for $1 \mathrm{~min}$, and this involved walking with the net through the water, dragging and kicking of macrophyte vegetation, rocks and sediment was done to dislodge macroinvertebrates attached. Active animals were prevented from escaping in the net by quickly lifting it out of the water and emptying the contents into a tray, where all detrital organic matter was removed. The macroinvertebrates were then moved into a labelled $500-\mathrm{mL}$ polyethylene bottles and preserved in $70 \%$ ethanol. Identification and counting of macroinvertebrates was done in the laboratory under a disserting Olympus microscope using guides by Gerber and Gabriel (2002), and taxa were identified to family level.

\section{Habitat assessment and substrate characterisation}

Habitat assessment was done at each site, and the assessment was based on the following categories: erosion and stability, in-stream cover, bank vegetation and verge vegetation. The assessment was based on modified habitat assessment form version 1.0 (West Gippsland Water Management Authority, Victoria). Substrate embeddedness determination was based on a method by Platts et al. (1983): (1)>75\%; (2) 50-75\%; (3) $25-50 \%$; (4) $5-25 \%$; and (5) $<5 \%$ of benthic surface covered by fine (i.e. clay/silt) sediment.

\section{Macrophyte sampling}

Macrophyte cover was visually checked and expressed as percentage (\%) at each site. A standard transect length (i.e. $100 \mathrm{~m}$ ) was selected at each of the four sites on both sides of the wetland and assessed to confirm its suitability for the survey and then marked (Dawson 2002; Hering et al. 2006; Dalu et al. 2012). Macrophyte community structure within the wetlands and the physical character of the study area were surveyed by wading in a zigzag manner across the wetland transect length, investigating all the different habitat types present. Macrophyte percentage cover was described in eight randomly selected quadrats $(1 \mathrm{~m} \times 1 \mathrm{~m})$ within each transect. Care was taken to examine all the small niches available within each quadrat/transect so as to observe all possible macrophyte species. Identification of the macrophytes was done to species level where possible using field identification guides by Gerber et al. (2004).

\section{Data analysis}

Using Shapiro-Wilk normality test confirmed that the environmental and biotic data accumulated were not normal. The collected data did not meet the expectations of parametric tests such as normality and homogeneity of variance. Thus, a nonparametric test Kruskal-Wallis was used to test for differences in environmental and biotic variables among sites

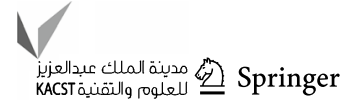


and seasons using STATISTICA version 12.0 (StataCorp 2011). The level of $p<0.05$ was accepted as the minimum significance level.

Common macroinvertebrate metrics were used to assess the environmental integrity: \%Ephemeroptera abundance, \% Trichoptera abundance and \%Diptera abundance, and Shannon-Wiener diversity index. The South African Scoring System version 5 (SASS5) score, which is the sum of all macroinvertebrates pre-determined taxa tolerance values to pollution within a sample, and the average score per taxon (ASPT), calculated by dividing the SASS5 score by the sample taxa number (Dickens and Graham 2002) were computed to assess wetland quality. The SASS5 and ASPT scores were used as a measure of each site condition: excellent (SASS5 score $>100$ and ASPT score $>7)$, good (80-100 and 5-7), fair (60-80 and 3-5), poor (40-60 and 2-3) and very poor $(<40$ and $<2)$ (Thirion et al. 1995).

To evaluate seasonal changes in macrophyte community structure among sites and seasonal separation within the Sambandou wetlands, a non-metric multidimensional scaling ( $n$-MDS) analysis with Euclidean dissimilarity as a measure of distance was carried out (Kruskal and Wish 1978) using PC-ORD version 5.10 in quick and dirty mode. Preliminary de-trended correspondence analysis (DCA) was applied to the macroinvertebrate dataset to determine the length of the gradient. The DCA revealed that the gradient was greater than 3 standard deviation units (i.e. 4.74), justifying the use of unimodal ordination techniques (Ter Braak and Verdonschot 1995). Thus, canonical correspondence analysis (CCA) was used to investigate relationships between predictor variables and benthic macroinvertebrate communities from different sites. Preliminary CCA identified collinear variables and selected a subset on inspection of variance inflation factors (VIF $<20$; Ter Braak and Verdonschot 1995). Monte Carlo permutation tests (9999 unrestricted permutations, $p<0.05$ ) were used to test the significance of the axis and hence determine whether the selected environmental variables could explain nearly as much variation in the macroinvertebrate data as all the measured environmental variables combined. CCA was performed using CANOCO version 5.1 (Ter Braak and Šmilauer 2002).

\section{Results}

\section{Environmental variables}

Six environmental variables (i.e. temperature, total dissolved solids (TDS), Conductivity, $\mathrm{pH}$ and turbidity) showed significant differences $(p<0.05)$ across the two seasons, whereas three variables, i.e. conductivity, dissolved oxygen (DO) and phosphate concentration, were significantly different $(p<0.05)$ among the study sites (Table 1$)$. Conductivity

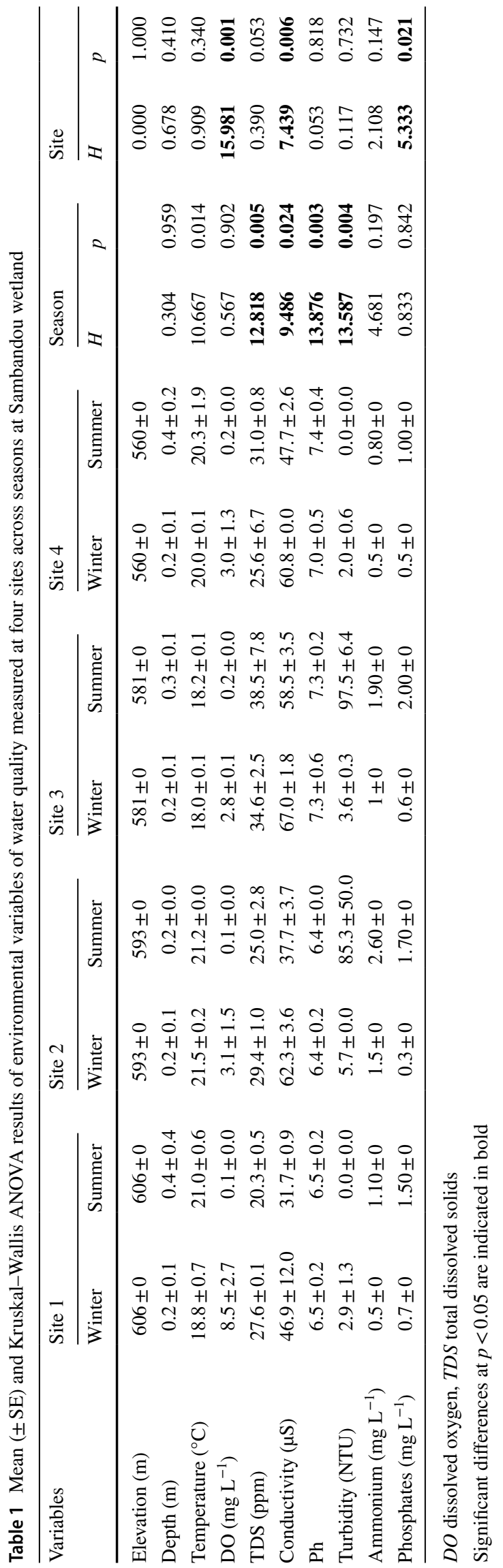


and TDS were generally high during the winter with concentrations increasing from the upper (site 1) to lower reach (site 4). Similar trends were also observed for turbidity and $\mathrm{pH}$, with $\mathrm{pH}$ being slightly acidic at site $1(\mathrm{pH}$ mean value $=6.5$ ) changing to slightly alkaline in summer (i.e. 7.4) (Table 1). High ammonium and phosphate concentration was recorded during summer season at sites 2 and 3 , respectively (Fig. 2). Ammonium ranged from 0.5 to $1.5 \mathrm{mg} \mathrm{L}^{-1}$ in winter, whereas in summer it ranged from 0.8 to $2.6 \mathrm{mg} \mathrm{L}^{-1}$. Phosphates ranged from 0.3 to $0.7 \mathrm{mg} \mathrm{L}^{-1}$ in winter and $1.0-2.0 \mathrm{mg} \mathrm{L}^{-1}$ during summer. The Kruskal-Wallis analysis showed significant $(p<0.05)$ site variation for phosphates (Table 1).

\section{Chlorophyll-a concentration}

The chl- $a$ concentration increased from a low in winter to a high in summer (Fig. 2). Picophytoplankton and microphytoplankton concentration decreased from winter to low concentrations during summer, whereas nanophytoplankton concentration increased from winter to high concentrations in summer (Fig. 2). The chl- $a$ concentration generally increased from site $1\left(\sim 0.5 \mathrm{mg} \mathrm{L}^{-1}\right)$ to $4\left(\sim 1.2 \mathrm{mg} \mathrm{L}^{-1}\right)$ during the winter (Fig. 2), whereas an opposite trend was observed for summer, with chl- $a$ concentration decreasing from site 1-4 (Fig. 2). During winter, picophytoplankton dominated sites 1 and 4 , whereas microphytoplankton dominated sites 2 and 3 (Fig. 2). In summer, the chl- $a$ concentration was dominated by nanophytoplankton (Fig. 2). Picophytoplankton ranged from 0.03 to $0.70 \mathrm{mg} \mathrm{L}^{-1}$ during winter, whereas in summer it ranged from 0.24 to $0.66 \mathrm{mg} \mathrm{L}^{-1}$. Nanophytoplankton biomass ranged from 0.11 to $046 \mathrm{mg} \mathrm{L}^{-1}$ in winter and $0.81-4.13 \mathrm{mg} \mathrm{L}^{-1}$ in summer. For microphytoplankton, the range was $0.10-0.60 \mathrm{mg} \mathrm{L}^{-1}$ in winter and $0.23-0.82 \mathrm{mg} \mathrm{L}^{-1}$ in summer. Chlorophyll- $a$ concentration was found to be negatively correlated with elevation $(r=-0.97, p<0.001)$ and habitat structure $(r=-0.48$, $p=0.012)$ and positively correlated with conductivity $(r=0.55, p=0.004)$ and $\mathrm{pH}(r=0.62, p=0.001)$.

\section{Macrophytes}

Phragmites mauritianum, Potamogeton pectinatus, Cyperus sp., Cyperus sexangularis and Nymphaea naouchalia var. coerulea were species that were observed in the Sambandou wetland (Table 2). The most abundant species observed was P. mauritianum ranging from 10 to $60 \%$, whereas $P$. pectinatus and Cyperus spp. were less abundant ranging from 5 to $15 \%$ and 1 to $30 \%$, respectively. The $n$-MDS ordination based on macrophyte taxa discriminated among seasons
Fig. 2 Size-fractionated chlorophyll- $a$ concentration $\left(\mathrm{mg} \mathrm{L}^{-1}\right)$ measured from Sambandou wetland
Table 2 Macrophyte species observed (\% cover) from Sambandou wetland

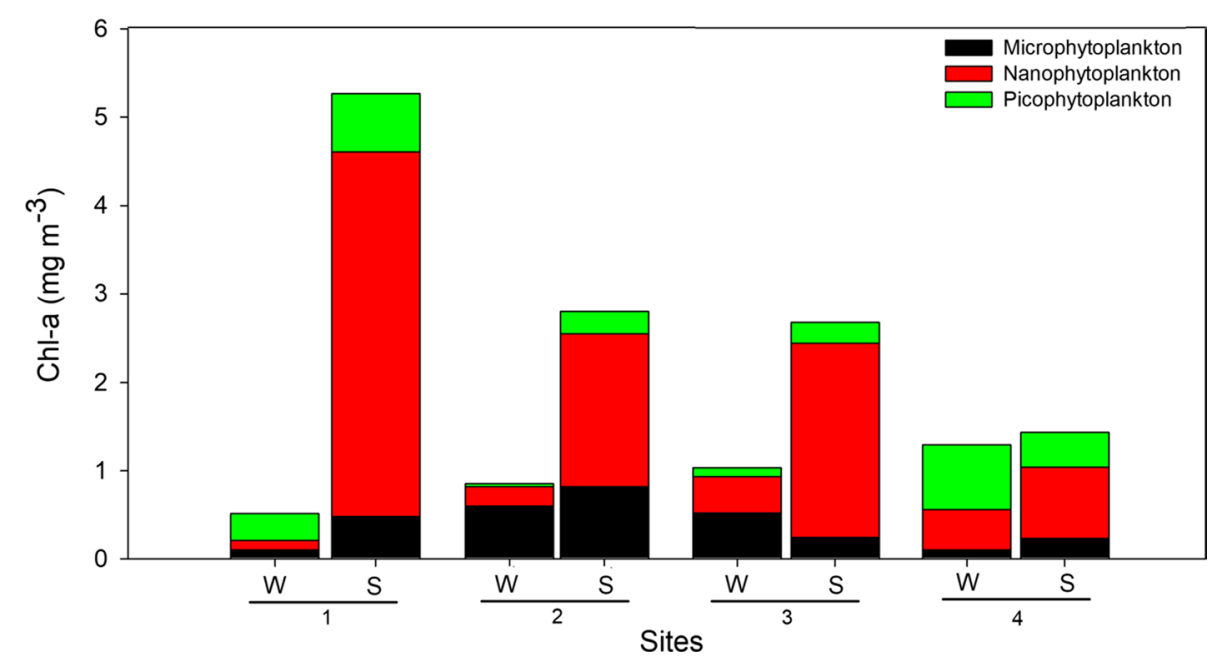

\begin{tabular}{|c|c|c|c|c|c|c|c|c|}
\hline \multirow[t]{2}{*}{ Macrophyte } & \multicolumn{4}{|l|}{ Winter } & \multicolumn{4}{|c|}{ Summer } \\
\hline & Site 1 & Site 2 & Site 3 & Site 4 & Site 1 & Site 2 & Site 3 & Site 4 \\
\hline Cyperus sp. & 30 & 10 & 1 & 2 & 8 & 30 & 5 & 1 \\
\hline Nymphaea naouchalia var. coerulea & 1 & & 20 & & 1 & & 20 & \\
\hline Potamogeton pectinatus & 5 & & & & 15 & & & \\
\hline Phragmites mauritianum & 50 & 50 & 60 & 10 & 20 & 20 & & 30 \\
\hline Cyperus sexangularis & 1 & 30 & 1 & 1 & 2 & 5 & & 1 \\
\hline
\end{tabular}


Fig. $3 n$-MDS ordination (stress value 0.12 ) highlighting variation of macrophyte communities across sites and seasons. Polygons indicate the two seasons: green-summer and brown-winter

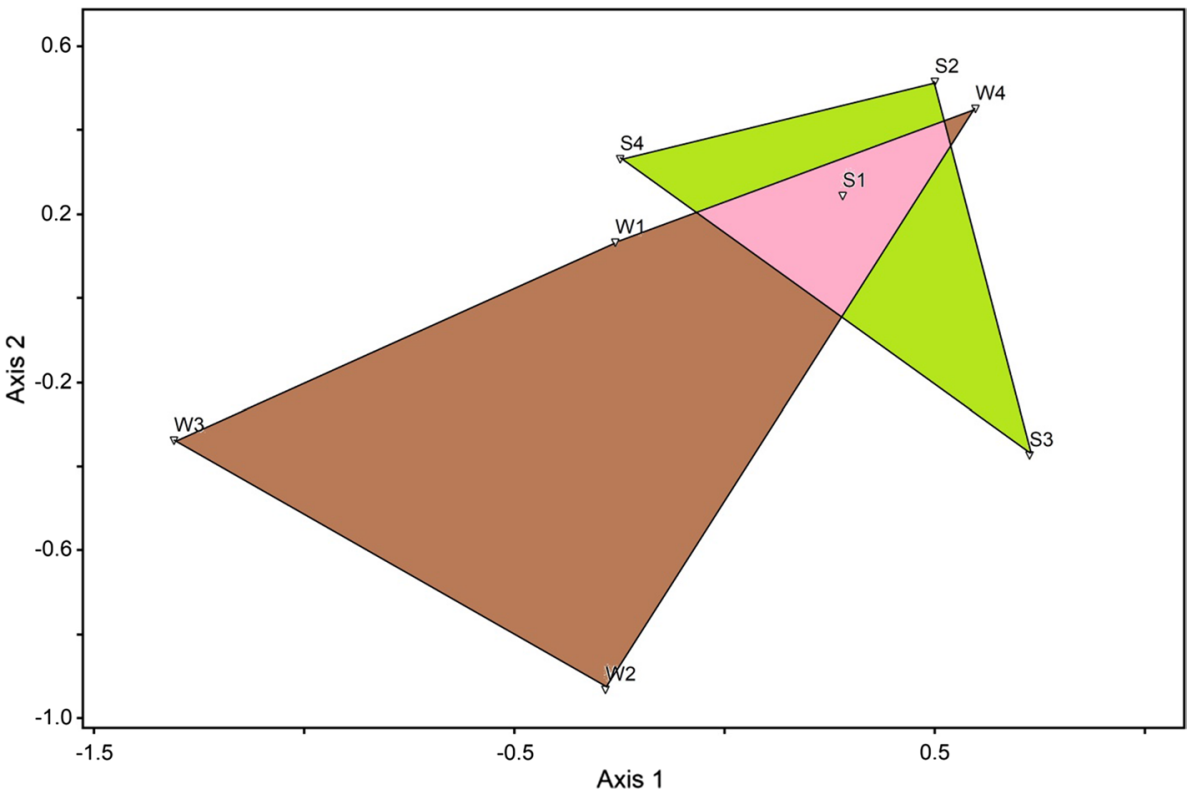

(Fig. 3). Macrophyte cover was negatively correlated with chl- $a$ concentration $(r=-0.47, p=0.013)$ and positively correlated with elevation $(r=0.60, p=0.002)$, TDS $(r=0.36$, $p=0.049)$ and habitat structure $(r=0.70, p<0.001)$.

\section{Macroinvertebrates}

A total of fifteen macroinvertebrate families were identified over two seasons (Table 3). Taxa richness ranged between 3 and 5 per site in winter to between 2 and 4 in summer (Table 3). Chironomidae were the most abundant family. A high Shannon-Weiner diversity index was observed during summer. The Shannon-Weiner diversity index was negatively correlated with TDS $(r=-0.43, p=0.024)$ and conductivity ( $r=-0.50, p=0.009)$, and positively correlated with SASS score $(r=0.47, p=0.013)$ and ASPT score $(r=0.54, p=0.005)$.

The SASS5 scores were generally low for both seasons ranging between 7 and 23, with site 4 having the lowest SASS scores for the two seasons. The scores generally reflected poor water quality for both seasons. The ASPT scores indicated that the condition of water quality was fair in winter for sites 1-3, with site 4 having good water quality. The SASS scores were negatively correlated with TDS $(r=-0.48, p=0.013), \mathrm{pH}(r=-0.64, p=0.001)$ and chl- $a$ concentration $(r=-0.74, p<0.001)$, and positively correlated with elevation $(r=0.77, p<0.001)$ and habitat structure $(r=0.51, p=0.007)$. Overall in summer, the water quality condition was good for sites $1-3$, with site 4 having a fair condition and the opposite was observed for the winter season (Fig. 4). The \% Trichoptera and \%Diptera were high at sites 4 and 2 during winter, with \%Coleoptera being high in site 2 for summer season.

\section{Relationship between macroinvertebrates and environmental/biotic variables}

The CCA highlighted seven variables, i.e. $\mathrm{pH}$, phosphate concentration, temperature, Ammonium, macrophyte cover, conductivity and water depth, which were significant in structuring macroinvertebrate community (Fig. 5). The CCA axes $1(23.7 \%)$ and $2(21.4 \%)$ accounted for $45.1 \%$ of the total macroinvertebrate community and environmental/biotic variation. The CCA axis 1 generally separated the winter and summer sites in the study area. The winter sites were mostly negatively associated with CCA axis 1 and were characterised by high temperature, phosphate and ammonium concentration, macrophyte cover, conductivity and $\mathrm{pH}$. Examples of macroinvertebrates that were associated with these sites include Aeshnidae, Coenagrionidae, Corixidae, Gerridae and Chironomidae. Summer sites were positively associated with axis 1 and were characterised by high water depth and pH levels (Fig. 5). Examples of macroinvertebrates that were associated with these sites included Baetidae, Pleidae, Gomphidae and Libellulidae (Fig. 5).

\section{Habitat assessment}

The Sambandou wetland was degraded mostly due to agricultural activities that were observed within the wetland such as cattle grazing and cultivation (Fig. 6a, c, d) and sand mining (i.e. sand poaching; Fig. 6b, c). There was settlement near the wetland and cultivation within the wetland was mostly vegetables, potatoes, maize and sugarcane. The wetland habitat rating for site 1 was fair $(68 \%)$, site 2 was excellent (97\%) and site 3 was good (80\%). Habitat rating 
Table 3 Macroinvertebrates relative abundance $(\%)$ observed at four sites over two seasons (summer, winter)

\begin{tabular}{|c|c|c|c|c|c|c|c|c|}
\hline \multirow[t]{2}{*}{ Family } & \multicolumn{4}{|c|}{ Winter } & \multicolumn{4}{|c|}{ Summer } \\
\hline & Site 1 & Site 2 & Site 3 & Site 4 & Site 1 & Site 2 & Site 3 & Site 4 \\
\hline \multicolumn{9}{|l|}{ Coleoptera } \\
\hline Dytiscidae & & & 12 & & & & & \\
\hline Gyrinidae & & & & & & 61 & & \\
\hline \multicolumn{9}{|l|}{ Diptera } \\
\hline Chironomidae & 10 & 59 & & 20 & & & & \\
\hline Psychodidae & & 1 & & & & & & \\
\hline \multicolumn{9}{|l|}{ Ephemeroptera } \\
\hline Baetidae & & & 6 & & & & & \\
\hline Leptophlebiidae & & & & & 29 & & & \\
\hline \multicolumn{9}{|l|}{ Hemiptera } \\
\hline Corixidae & & & 6 & & & & & \\
\hline Gerridae & 5 & & & & & 11 & & \\
\hline Pleidae & & & & & 14 & & & \\
\hline \multicolumn{9}{|l|}{ Odonata } \\
\hline Aeshnidae & 5 & 9 & & 20 & & 11 & 20 & \\
\hline Libellulidae & 10 & 20 & 70 & & 43 & 17 & 80 & \\
\hline Gomphidae & & & & & 14 & & & \\
\hline Coenagrionidae & 70 & 11 & 6 & & & & & 60 \\
\hline \multicolumn{9}{|l|}{ Trichoptera } \\
\hline Ecnomidae & & & & 60 & & & & \\
\hline \multicolumn{9}{|l|}{ Crustacea } \\
\hline Potamonautidae & & & & & & & & 40 \\
\hline SASS score & 23 & 19 & 20 & 18 & 23 & 22 & 12 & 7 \\
\hline ASPT score & 4.6 & 3.8 & 4.0 & 6.0 & 5.8 & 6.7 & 6.0 & 3.5 \\
\hline Taxa richness & 5 & 5 & 5 & 3 & 4 & 3 & 2 & 2 \\
\hline Shannon-Weiner & 1.01 & 0.15 & 1.00 & 0.95 & 1.00 & 1.28 & 0.40 & 0.67 \\
\hline
\end{tabular}

$A S P T$ average score per taxa, SASS5 South African Scoring System version 5

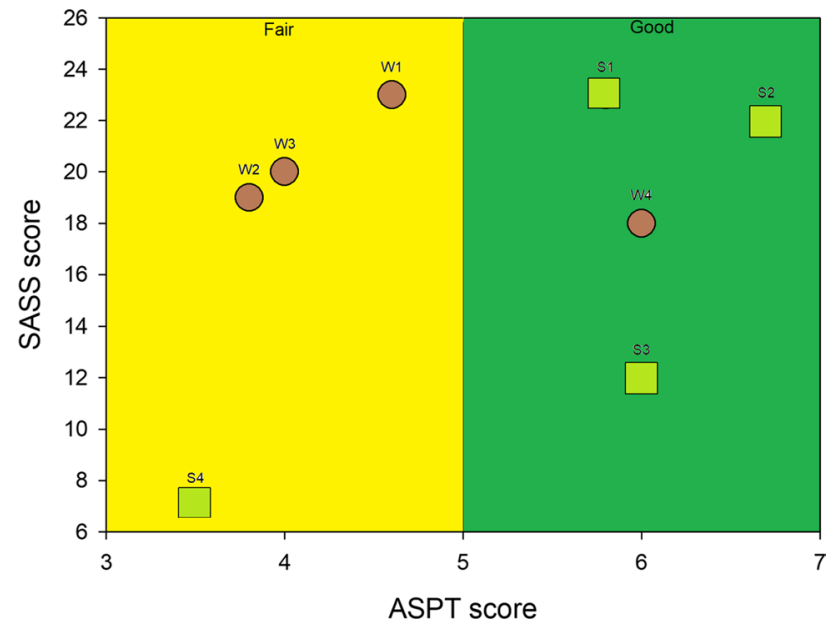

Fig. 4 Mean ASPT and SASS scores calculated for Sambandou wetland sites over two seasons

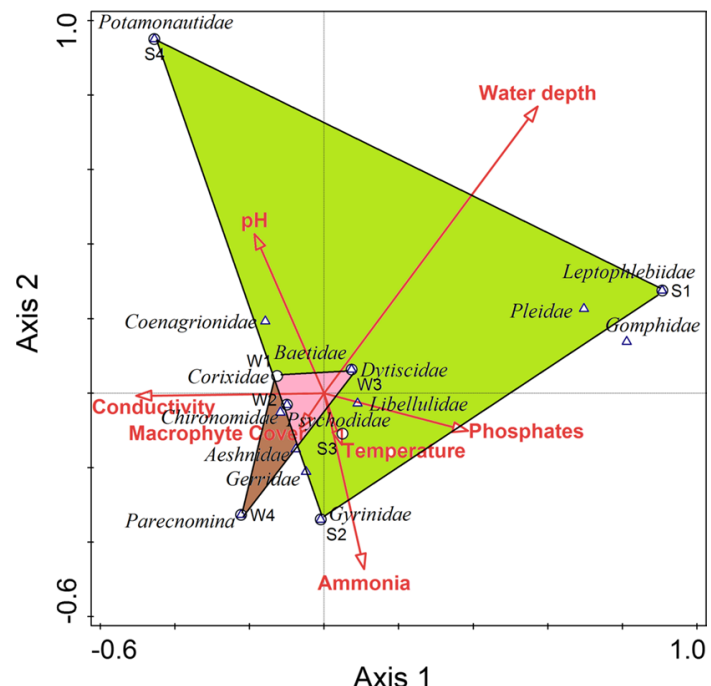

Fig. 5 Canonical correspondence analysis (CCA) showing the relationship between environmental variables and macroinvertebrates. Polygons indicate the two seasons: green-summer and brown-winter 

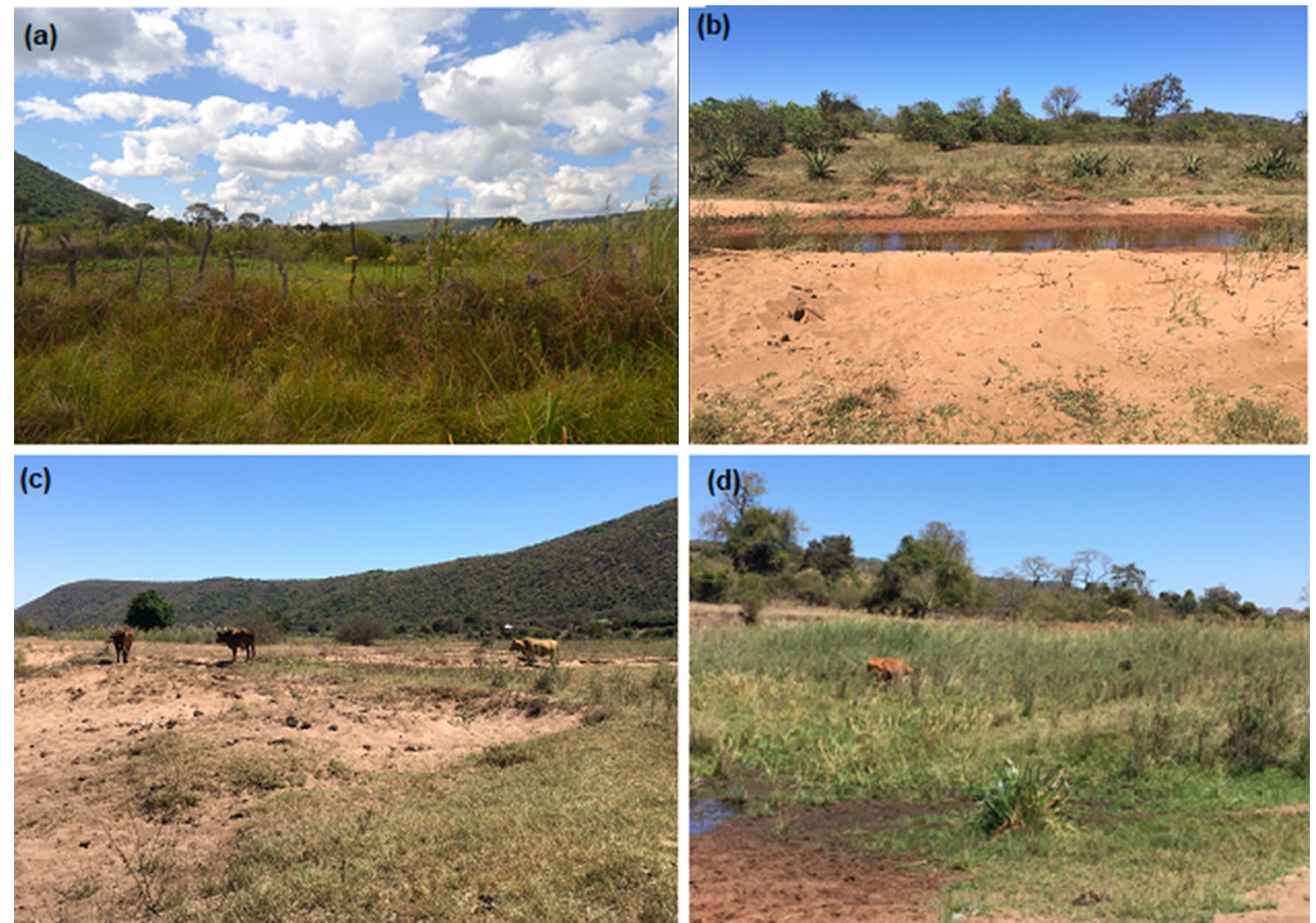

Fig. 6 Wetland degradation observed within the Sambandou wetlands: a wetland cultivation (site 2), b sand mining/poaching (site 4), c sand mining/poaching and cattle grazing causing erosion (site 1), and $\mathbf{d}$ cattle grazing (site 1)

for site 4 was poor (40\%), and the site was heavily eroded, which may be a result of sand mining (i.e. sand poaching) and cattle grazing as a lot of cattle dung was observed within the study site. Habitat structure was negatively correlated with $\mathrm{pH}(r=-0.47, p=0.014)$ and was positively correlated with elevation $(r=0.69, p<0.001)$, turbidity $(r=0.56$, $p=0.009)$ and ammonium $(r=0.76, p<0.001)$.

\section{Discussion}

The study assessed macroinvertebrate communities in relation to environmental and biotic variables in Sambandou wetlands. The results showed that the measured environmental (i.e. water depth, ammonium, conductivity, $\mathrm{pH}$ and phosphates) and biotic (macrophyte cover) variables had an effect on macroinvertebrate communities. The macroinvertebrate richness varied among two seasons (winter and summer), being generally high in summer. The CCA analysis highlighted that summer sites were positively associated with high $\mathrm{pH}$ concentration (Fig. 4), and at local spatiotemporal scales most studies do not report the significance of $\mathrm{pH}$ as an environmental variable influencing macroinvertebrate community structure (Nhiwatiwa et al. 2017b). However, at regional scales where landscape differences are significant, it has been shown to be an influential factor (Nicolet et al. 2004).

Water depth, conductivity, ammonium, conductivity, $\mathrm{pH}$, phosphates and macrophyte cover were significant variables affecting macroinvertebrate community structuring as highlighted by the CCA analysis. Although they have a high adaptability to a wide range of ecological conditions, benthic macroinvertebrates can also actively select for suitable aquatic habitats (Batzer et al. 2004). This also has significant links with the importance of water depth on macroinvertebrate community structure and composition (Nhiwatiwa et al. 2017a). Nutrients such as phosphates and ammonium concentration were very high in summer, and these strongly affected macroinvertebrate communities. The grazing of cattle could have had a strong impact on wetlands by increasing nutrient input through urine and faecal deposition (Steinman and Rosen 2000). The wetland was cultivated on and cow dung used as manure, and several studies have highlighted that nutrient concentrations in the aquatic ecosystems can increase due to the application of manure and fertilisers (Bainbridge 2009).

While seasonality can play an important and key driver of macroinvertebrate community dynamics, its effect is 
regulated by the predictability of its recurrence (Tonkin et al. 2017). For instance, in our study, highly predictable seasonal rainfall leads to more or less regular oscillations in distinct macroinvertebrate community types (see Fig. 5), but further long-term studies are required to verify the patterns in greater detail. By contrast, in Nigerian streams, Tonkin et al. (2016) found little seasonality role in shaping river macroinvertebrate community structure due to weak and unpredictable seasonality (Tonkin et al. 2017).

Chironomidae were the most abundant family during summer, whereas in winter Chironomidae were not identified. These results are similar the findings of Odume and Muller (2011) and Dalu et al. (2017b) who observed increased Chironomidae diversity during the summer season. Chironomidae taxa are tolerant to water pollution. High macroinvertebrate taxon richness was observed only in winter when there were less impacts occurring within the wetland.

A high chl- $a$ concentration in the wetland is an indicator of potential eutrophication, which is harmful to many aquatic organisms and reduces biodiversity (Mereta et al. 2013). As expected, the chl- $a$ concentration was high along a nutrient gradient, i.e. increasing nutrient concentrations similar to findings by Corkum (1996) and Dalu et al. (2014) studies. The study results indicated that the macroinvertebrate abundance and community structure changed with increasing chl$a$, ammonium and phosphates concentration, with a single family grouping dominating. These results are in contrast to Kendrick et al. (2019) who observed increased phytoplankton biomass and invertebrate production. From the study findings, we can deduce that when nutrient resources supply were low especially during summer, phytoplankton was dominated by small-sized cells, i.e. pico- and nanophytoplankton, whereas the large-sized cell fractions increased as nutrients increased for sites 2 and 3 in winter where gardens were located, becoming dominant in highly productive ecosystems (Chisholm 1992; Li 2002). These contrasting phytoplankton community structures also relate to different ecosystem functioning modes. Under nutrient limitation, an ecosystem will maximize nutrient recycling, while new primary production based on inputs from allochthonous sources generally supports highly productive ecosystems resulting in dominance of a large number of large-celled phytoplankton, i.e. microphytoplankton similar to winter sites 2 and 3 (Eppley and Peterson 1979; Cózar et al. 2018).

The macrophyte composition consisted of five taxa which were identified (i.e. Phragmites mauritianum, Potamogeton pectinatus, Cyperus sp., Cyperus sexangularis and Nymphaea naouchalia var. coerulea), and these followed a dynamic pattern which was more pronounced for individual macrophyte species within the wetland. The overlap observed between winter and summer could be attributed to habitat degradation due to sand mining/poaching and agriculture for the sites in question (Fig. 3). Similar to Dalu et al.
(2012), the differences among sites in macrophyte species structure and composition was also attributed to substrate structure heterogeneity. Thus, habitat structure influence on macrophyte spatial distribution has long been discussed in detail in several studies (e.g. Machena 1987; BaattrupPedersen and Riis 1999; Brendonck et al. 2003). The study findings were also similar to those by Machena (1987) who observed that most submerged macrophytes were associated with extreme environmental conditions (gravel and rocky substrates). The diversity of macrophytes in wetlands creates a more heterogeneous environment which also contributes to increased macroinvertebrate diversity, for example shredders and scrappers (gastropods) which depend on macrophytes as food source and substrate (Gooderham and Tsyrlin 2002). However, in the current study, habitat complexity was unrelated to macroinvertebrate taxa richness and McAbendroth et al. (2005) also observed similar findings.

\section{Conclusions}

The study results indicated that environmental and biotic variables influenced macroinvertebrate communities. Anthropogenic activities such as agriculture (i.e. cattle grazing, cultivation) and urban developments have resulted in increased nutrient concentrations, which might have had a significant negative effect on macroinvertebrate communities. More studies are therefore required so as to understand how macroinvertebrates are structured in relation to land-use activities and also how anthropogenic activities impact of the health status of the Sambandou wetlands within the Vhembe Biosphere Reserve.

Acknowledgements The study was funded by the University of Venda Niche Fund (SES/18/ERM/10) and RC would like to acknowledge the National Research Foundation (NRF) BSc Hons Bursary. We would to thank Salphina Sathekge, Benard Malesa and Mulweli Makatu for assisting during field work.

\section{Compliance with ethical standards}

Conflict of interest The authors declare that they have no conflict of interest.

Ethical approval All experiments were carried out in compliance with the ethical clearance approved by the University of Venda Research Committee (No. SES/18/ERM/10/1009).

Open Access This article is distributed under the terms of the Creative Commons Attribution 4.0 International License (http://creativeco mmons.org/licenses/by/4.0/), which permits unrestricted use, distribution, and reproduction in any medium, provided you give appropriate credit to the original author(s) and the source, provide a link to the Creative Commons license, and indicate if changes were made. 


\section{References}

Alkorta I, Garbisu C (2001) Phytoremediation of organic contaminants in soils. Bioresour Technol 79(3):273-276

Allan JD (2004) Influence of land use and landscape setting on the ecological status of rivers. Limnetica 23(3-4):187-197

Arheimer B, Löwgren M, Pers BC, Rosberg J (2005) Integrated catchment modelling for nutrient reduction: scenarios showing impacts, potential, and cost of measures. Ambio 34:513-520

Baattrup-Pedersen A, Riis T (1999) Macrophyte diversity and composition in relation to substratum characteristics in regulated and unregulated Danish streams. Freshw Biol 42:375-385

Bainbridge SH (2009) Phosphorus sorption in Natal soils. S Afr J Plant Soil 12:59-64

Batzer DP, Palik BJ, Buech R (2004) Relationships between environmental characteristics and macroinvertebrate communities in seasonal woodland ponds of Minnesota. J N Am Benthol Soc 23:50-68

Bonada N, Prat N, Resh VH, Statzner B (2006) Developments in aquatic insect biomonitoring: a comparative analysis of recent approaches. Annu. Rev. Entomol. 51:495-523

Brand C, Miserendino ML (2015) Testing the performance of macroinvertebrate metrics as indicators of changes in biodiversity after pasture conversion in Patagonian Mountain streams. Water Air Soil Pollut 226(11):370

Brendonck L, Maes J, Rommens W, Dekeza N, Nhiwatiwa T, Barson M, Callebaut V, Phiri C, Moreau K, Gratwicke B, Stevens M (2003) The impact of water hyacinth (Eichhornia crassipes) in a eutrophic subtropical impoundment (Lake Chivero, Zimbabwe). II. Species diversity. Archiv Für Hydrobiol 158:389-405

Chisholm SW (1992) Phytoplankton size in primary productivity and biogeochemical cycles in the sea. In: Falkowski PG, Woodhead $\mathrm{AD}$ (eds) primary productivity and biogeochemical cycles in the sea. Plenum Press, New York

Corkum LD (1996) Responses of chlorophyll-a, organic matter, and macroinvertebrates to nutrient additions in rivers flowing through agricultural and forested land. Archiv für Hydrobiol 136:391-411

Cózar A, Morillo-García S, Ortega MJ, Li QP, Bartual A (2018) Macroecological patterns of the phytoplankton production of polyunsaturated aldehydes. Sci Rep 8:12282

Dalu T, Clegg B, Nhiwatiwa T (2012) Aquatic macrophytes in a tropical African reservoir: diversity, communities and the impact of reservoir-level fluctuations. Trans R Soc S Afr 67:117-125

Dalu T, Froneman PW, Richoux NB (2014) Phytoplankton community diversity along a river estuary continuum. Trans R Soc S Afr 69:107-116

Dalu T, Wasserman RJ, Dalu MT (2017a) Agricultural intensification and drought frequency increases may have landscape-level consequences for ephemeral ecosystems. Glob Change Biol 23:983-985

Dalu T, Wasserman RJ, Tonkin JD, Alexander ME, Dalu MT, Motitsoe SN, Manungo KI, Bepe O, Dube T (2017b) Assessing drivers of benthic macroinvertebrate community structure in African highland streams: an exploration using multivariate analysis. Sci Total Environ 601:1340-1348

Dalu T, Wasserman RJ, Tonkin JD, Mwedzi T, Magoro ML, Weyl OLF (2017c) Water or sediment? Partitioning the role of water column and sediment chemistry as drivers of macroinvertebrate communities in an austral South African stream. Sci Total Environ $607: 317-325$

Dawson H (2002) Guidance for the field assessment of macrophytes of rivers within the STAR project. Second update. NERC CEHDorset, Oxford, pp 1-98
Dickens CWS, Graham PM (2002) The South African Scoring System (SASS) version 5 rapid bioassessment method for rivers. Afr J Aquat Sci 27:1-10

Eppley RW, Peterson BJ (1979) Particulate organic matter fux and planktonic new production in the deep ocean. Nature 282:677-680

Gerber A, Gabriel MJM (2002) Aquatic Invertebrates of South African Rivers Field Guide. Resource Quality Services, Department of Water Affairs and Forestry, Pretoria

Gerber A, Cilliers CJ, van Ginkel C, Glen R (2004) Easy identification of aquatic plants: a guide for the identification of water plants in and around South African impoundments. Department of Water Affairs, Pretoria

Gooderham J, Tsyrlin E (2002) The Waterbug book: a guide to the freshwater macroinvertebrates of temperate Australia. CSIRO Publishing, Collingwood

Hering D, Johnson RK, Kramm S, Schumtz S, Szoszkiewicz K, Verdonschot PFM (2006) Assessment of European streams with diatoms, macrophytes, macroinvertebrates and fish: a comparative metric-based analysis of organism response to stress. Freshw Biol 51:1757-1785

Kendrick MR, Hershey AE, Huryn AD (2019) Disturbance, nutrients, and antecedent flow conditions affect macroinvertebrate community structure and productivity in an Arctic river. Limnol Oceanogr 64:S93-S104

Kruskal JB, Wish M (1978) Multidimensional scaling. Sage University paper series on quantitative applications in the social sciences. Sage Publishers, Beverly Hills

Li WK (2002) Macroecological patterns of phytoplankton in the northwestern North Atlantic ocean. Nature 419:154-157

Lorenzen CJ (1967) Determination of chlorophyll and phaeophytin. Spectrophotometric equations. Limnol Oceanogr 12:343-346

Macedo DR, Hughes RM, Ferreira WR, Firmiano KR, Silva DR, Ligeiro R, Kaufmann PR, Callisto M (2016) Development of a benthic macroinvertebrate multimetric index (MMI) for Neotropical Savanna headwater streams. Ecol Indic 64:132-141

Machena C (1987) Zonation of submerged macrophyte vegetation in Lake Kariba, Zimbabwe and its ecological interpretation. Vegetatio 73:111-119

Malinga R, Gordon LJ, Jewitt G, Lindborg R (2015) Mapping ecosystem services across scales and continents-A review. Ecosyst Serv 13:57-63

Mangadze T, Dalu T, Froneman PW (2019) Biological monitoring in southern Africa: a review of the current status, challenges and future prospects. Sci Total Environ 648:1492-1499

McAbendroth L, Ramsay PM, Foggo A, Rundle SD, Bilton DT (2005) Does macrophyte fractal complexity drive invertebrate diversity, biomass and body size distributions? Oikos 111:279-290

Mereta ST, Boetsa P, Meesterc L, Goethalsa P (2013) Development of a multimetric index based on benthic macroinvertebrates for the assessment of natural wetlands in Southwest Ethiopia. Ecol Indic 29:510-521

Millennium Ecosystem Assessment (2005) Ecosystems and human wellbeing. Wetlands and water synthesis, Washington, DC

Nhiwatiwa T, Dalu T, Brendonck L (2017a) Impact of irrigation based sugarcane cultivation on the Chiredzi and Runde Rivers quality, Zimbabwe. Sci Total Environ 587:316-325

Nhiwatiwa T, Brendonck L, Dalu T (2017b) Understanding factors structuring zooplankton and macroinvertebrate assemblages in ephemeral pans. Limnologica 64:11-19

Nicolet P, Biggs J, Fox G, Hodson MJ, Reynolds C, Whitfield M, Williams P (2004) The wetland plant and macroinvertebrate assemblages of temporary ponds in England and Wales. Biol Conserv 120:261-278 
Odume ON, Muller WJ (2011) Diversity and structure of Chironomidae communities in relation to water quality differences in the Swartkops River, South Africa. Phys Chem Earth 36:929-938

Ollis DJ, Dallas HF, Esler KJ, Boucher C (2006) Bioassessment of the ecological integrity of river ecosystems using aquatic macroinvertebrates: an overview with a focus on South Africa. Afr J Aquat Sci 31:205-227

Platts WS, Megahan WF, Minshall WG (1983) Methods for evaluating stream, riparian, and biotic conditions. General Technical Report INT-138, USDA Forest Service. Rocky Mountain Research Station, Ogden, UT

Rosenberg DM, Resh VH (1993) Introduction to freshwater biomonitoring and benthic macroinvertebrates. Chapman and Hall, New York

Sayadi MH, Sayyed MRG, Suyash K (2010) Short-term accumulative signatures of heavy metals in river bed sediments in the industrial area, Tehran. Environ Monit Assess 162:465-473

Sieburth JM, Smetacek V, Lenz J (1978) Pelagic ecosystem structure: Heterotrophic compartments of the plankton and their relationship to plankton size fractions ${ }^{1}$. Limnol Oceanogr 23(6):1256-1263
Steinman AD, Rosen BH (2000) Lotic-lentic linkages associated with Lake Okeechobee, Florida. J N Am Benthol Soc 4:17-733

Ter Braak CF, Šmilauer P (2002) CANOCO reference manual and cano draw for windows user's guide: software for canonical community ordination. Microcomputer Power, Ithaca

Thirion C, Mocke A, Woest R (1995) Biological monitoring of streams and rivers using SASS4: a user manual. Institute for Water Quality Studies, Department of Water Affairs and Forestry, Pretoria

Tonkin JD, Arimoro FO, Haase P (2016) Exploring stream communities in a tropical biodiversity hotspot: biodiversity, regional occupancy, niche characteristics and environmental correlates. Biodivers Conserv 25:975-993

Tonkin JD, Bogan MT, Bonada N, Rios-Touma B, Lytle DA (2017) Seasonality and predictability shape temporal species diversity. Ecology 98:1201-1216

Publisher's Note Springer Nature remains neutral with regard to jurisdictional claims in published maps and institutional affiliations. 